\title{
A Tower Model for Lightning Overvoltage Studies Based on the Result of an FDTD Simulation
}

Taku Noda Member (CRIEPI, takunoda@ieee.org)

Keywords: lightning protection, lightning overvoltage studies, transmission tower, tower model, FDTD method, and EMTP

\section{Abstract}

This paper describes a method for deriving a transmission tower model for EMTP lightning overvoltage studies from a numerical electromagnetic simulation result obtained by the FDTD (Finite Difference Time Domain) method. The FDTD simulation carried out in this paper takes into account the following items which have been ignored or over-simplified in previously-presented simulations: (i) resistivity of the ground soil; (ii) arms, major slant elements, and foundation structures of the tower; (iii) development speed of the lightning return stroke. For validation purpose a pulse test of a $500-\mathrm{kV}$ transmission tower is simulated, and a comparison with the measured result shows that the present FDTD simulation gives a sufficiently accurate result. Using this validated FDTDbased simulation method the insulator-string voltages of a tower for a lightning stroke are calculated, and based on the simulation result the parameter values of the proposed tower model for EMTP studies are determined in a systematic way. Since previously-presented models include trial-and-error process in the parameter determination, it can be said that the proposed model is more general in this regard. As an illustrative example, the $500-\mathrm{kV}$ transmission tower mentioned above is modeled, and it is shown that the derived model closely reproduces the FDTD simulation result.

\section{Main Results}

Figure 1 shows the simulation arrangement used in an FDTD simulation for obtaining the tower current $I_{T}$, the ground-wire current $I_{G}$, and upper-, middle-, and lower-phase insulator-string voltages $V_{H 1}, V_{H 2}$, and $V_{H 3}$. The simulation was carried out under a realistic condition as mentioned in the abstract above. The calculated result is shown in Fig. 2.

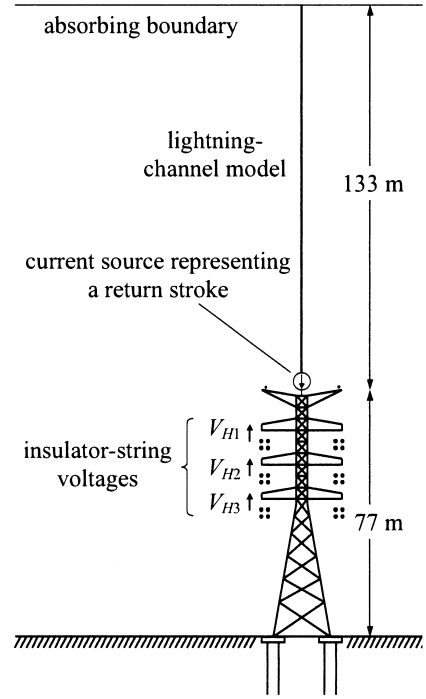

Fig. 1. Arrangement used in the FDTD simulation
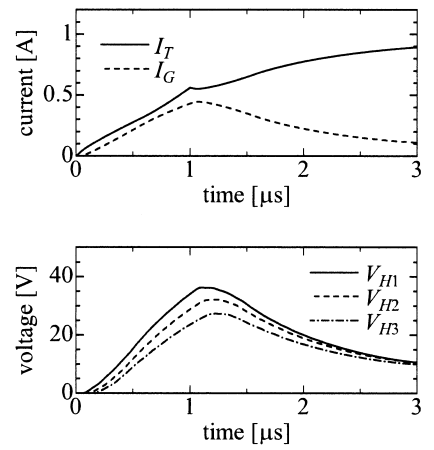

Fig. 2. FDTD simulation result

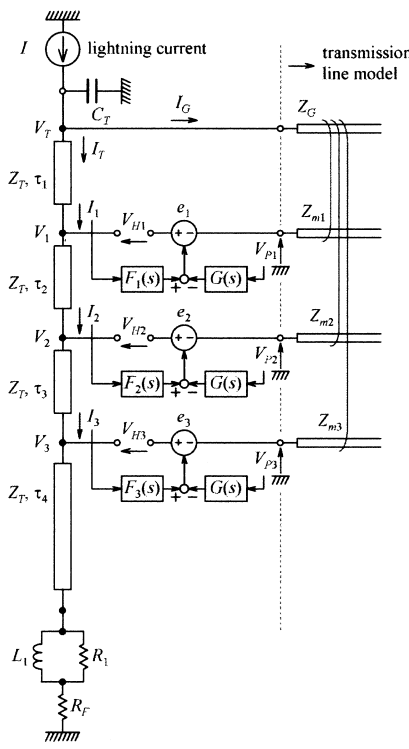

Fig. 3. Proposed tower model
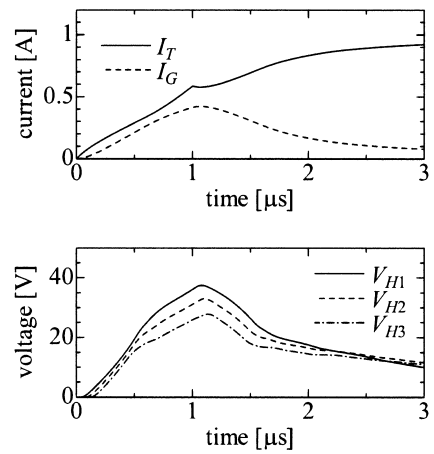

Fig. 4. EMTP simulation result
Figure 3 illustrates the proposed tower model that can be used for EMTP lightning overvoltage studies. The model basically follows the multi-story tower model but the following components are added: (1) $C_{T}$ : capacitance that simulates the time response of the voltage rise; (2) $e_{1}, e_{2}$, and $e_{3}$ : controlled voltage sources that represent the dynamic behavior of coupling between the ground wire and the phase wires and adjust the peak value of the insulator-string voltages with respect to a given FDTD result. Figure 4 shows the calculated result of $I_{T}, I_{G}, V_{H 1}, V_{H 2}$, and $V_{H 3}$ using EMTP with the proposed model. We can confirm that the proposed model closely reproduces the FDTD simulation result shown in Fig. 2. It is also mentioned in the paper that neighboring towers can basically be modeled by the proposed model. 


\title{
FDTD解析の結果に基づく雷サージ解析用鉄塔モデル
}

\author{
正員野田环*
}

\author{
A Tower Model for Lightning Overvoltage Studies Based on the Result of \\ an FDTD Simulation
}

Taku Noda*, Member

\begin{abstract}
This paper describes a method for deriving a transmission tower model for EMTP lightning overvoltage studies from a numerical electromagnetic simulation result obtained by the FDTD (Finite Difference Time Domain) method. The FDTD simulation carried out in this paper takes into account the following items which have been ignored or oversimplified in previously-presented simulations: (i) resistivity of the ground soil; (ii) arms, major slant elements, and foundations of the tower; (iii) development speed of the lightning return stroke. For validation purpose a pulse test of a 500-kV transmission tower is simulated, and a comparison with the measured result shows that the present FDTD simulation gives a sufficiently accurate result. Using this validated FDTD-based simulation method the insulator-string voltages of a tower for a lightning stroke are calculated, and based on the simulation result the parameter values of the proposed tower model for EMTP studies are determined in a systematic way. Since previously-presented models include trial-and-error process in the parameter determination, it can be said that the proposed model is more general in this regard. As an illustrative example, the $500-\mathrm{kV}$ transmission tower mentioned above is modeled, and it is shown that the derived model closely reproduces the FDTD simulation result.
\end{abstract}

キーワード：耐雷設計，雷サージ解析，送電鉄塔，鉄塔モデル，FDTD 法，EMTP

Keywords: lightning protection, lightning overvoltage studies, transmission tower, tower model, FDTD method, and EMTP

\section{1.はじめに}

送変電システムにおける供給支障の主な原因は，送電鉄 塔への雷撃である。送変電システムの耐雷設計や現有設備 の雷害リスクの把握には, 雷撃時に鉄塔の過渡応答により 生じる過電圧を正確に算定しておく必要がある。

送電鉄塔は，大地に対して垂直な導体であるため，分布 定数回路を含む電気回路論 (以降, 単に回路論と略す) の範 疇では正確に取り扱うことができない。これは，雷撃電流 が鉄塔上を塔頂から大地に向かって伝搬する途上では雷撃 電流が作る磁束は未だ鉄塔の近傍にしか生じておらず，ま た, 雷撃電流の電荷より生じた電気力線も大地には到達し ていないため, 鉄塔を分布定数回路として取り扱うのに必 要な直列インダクタンスや対地キャパシタンスを正確に定 義できないことによる。従って，鉄塔上を伝搬するサージ の解析には, 電磁界の準定常状態を前提とする（すなわち, 経路によらない電位を定義できる) 回路論的解析ではなく, マクスウェルの方程式に基づく動的な電磁界解析が必要と

\footnotetext{
* (財) 電力中央研究所 電力技術研究所

干 240-0196 横須賀市長坂 2-6-1

Electric Power Engineering Reseach Lab., CRIEPI

2-6-1, Nagasaka, Yokosuka 240-0196
}

なる ${ }^{(1)}$ 。垂直導体としての送電鉄塔単体のインピーダンス については, 回路論的アプローチ (2)(3) や電磁気学的アプロー チ ${ }^{(4) \sim(7)}$, 実験的アプローチ ${ }^{(8) \sim(10)}$ により研究が行われてき た。しかしながら，上述のとおり鉄塔上のサージ伝搬現象 は回路論では取り扱えないため, 鉄塔単体のインピーダン スを把握したとしても，それを用いて回路論的に算出した ホーン間電圧は正しいとはいえない。そこで, 実測や数值 電磁界解析手法を用いて雷撃電流に対するホーン間電圧を 求め, 物理性は若干無視した上で, そのホーン間電圧を再 現するような回路論的モデルを構築することが提案されて いる ${ }^{(11) \sim(13)}$ 。本来, 回路論的にはモデル化できない現象を回 路論的にモデル化するのであるから, 若干の物理性の無視 は止むを得ず，また，与えられた雷撃電流に対して耐雷設 計上最も重要であるホーン間電圧を正しく与えるため, こ れらのモデル化手法は実用上有用であると考えられる。回 路論の枠内でモデル化するため, EMTP (Electro-Magnetic Transients Program) (14) を用いた雷サージ解析に取り込める 利点も大きい。特に, 馬場らは, 数值電磁界解析手法の一 種であるモーメント法を用いた解析結果より, 一部試行錯 誤に基づくモデル定数決定過程を経て, モデル化を行う方 法を提案している ${ }^{(12)(13)}$ 。

本論文では, 数值電磁界解析の結果よりモデル化を行う 
という意味では馬場らの方法を踏襲しつつも, 次の点にお いて優れたモデル化手法を提案する。

(1) 数值電磁界解析手法として FDTD 法 (Finite Difference Time Domain Method）を採用することによ り，大地の抵抗率を考慮している。

（2）鉄塔のアームや斜材，土中の基礎構造，電力線 6 条全て (2 回線送電線の場合) を考慮して数值電磁 界解析を実施している。

（3）光速の約 $1 / 3$ といわれる埽還雷撃の進展速度を考 慮している。

（4）EMTP 解析に用いる回路論的モデルの定数決定は 一意に行われ，試行錯誤の過程がない。

提案手法では，極めて実際に近い条件で数值電磁界解析を 実施してホーン間電圧を求めており，また，モデル定数の 決定過程が試行錯誤の過程を含まないという特徵がある。 なお，本論文では，まず，過去に実施された $500 \mathrm{kV}$ 送電鉄 塔のサージ試験結果を FDTD 法により再現し，実測結果と の比較から FDTD 法の解析精度を検証する。次に, FDTD 法による解析結果に基づいて回路論の枠内で鉄塔のモデル 化を行い，ホーン間電圧を正しく再現できるモデルが得ら れることを示す。

\section{FDTD 法の解析精度の検証}

ここでは実測結果との比較により，FDTD 法の解析精度 の検証を行う。図 1 に過去に実施された $500 \mathrm{kV} ， 2$ 回線送 電鉄塔における塔頂電位上昇試験门の配置図を示す。測定 対象となった鉄塔は高さが $77 \mathrm{~m}$ の耐張型で，架空地線 2 条 $($ OPGW 290) と電力線 6 条 (ACSR $810 \times 4$ 導体) が架 線された状態で測定が行われた。パルス発生器 $(\mathrm{PG})$ を用 いて発生した矩形波状電流を電流注入補助線から塔頂に向 けて注入し，塔頂電位上昇として零電位線と塔頂の間に発 生する電圧が測定された。電流注入補助線と零電位線はそ れぞれ大地に対して水平に架設され遠方で接地されている が，観測時間内に接地端からの反射が戻ってこないよう水

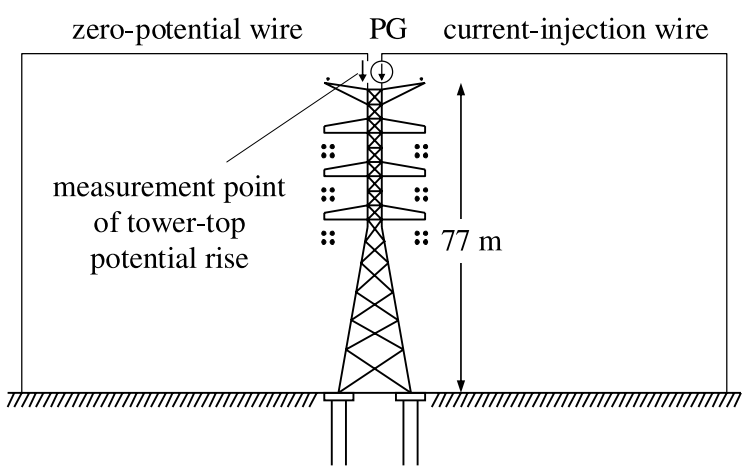

図 1 塔頂電位上昇試験配置図

Fig. 1. Arrangement for the measurement of tower-top potential rise.

\footnotetext{
†なお，この試験と併せて実施された衝撃電圧発生装置による試験 の結果については文献(15) で報告されている。
}

平部分が十分長くとられた (各々約 $100 \mathrm{~m}$ )。図 2 に測定結 果を示す。波高値 $1.37 \mathrm{~A}$ のほぼ矩形波の電流が注入され, 約 $600 \mathrm{~ns}$ でピーク值 $67.8 \mathrm{~V}$ をとる電位上昇波形が観測さ れた。

次に，この試験結果を FDTD 法によるシミュレーション で再現した結果について述べる。解析空間は水平方向を各 $250 \mathrm{~m}$, 垂直方向を $150 \mathrm{~m}$ とし, 空間刻みを $1 \mathrm{~m}$ とした。境 界面は全て 2 次の Liao の吸収境界面とし, 大地部分の導電 率を $250 \Omega \mathrm{m}$ に指定した（大地抵抗率マップによる当該地 域の抵抗率)。図 3 に解析で使用された鉄塔構造を示す。空 間刻みよりも小さな構造については表現できないが，それ より大きな構造については, 主材, 斜材, アーム, 基礎構造 等を含めできるだけ詳細に模擬した。架空地線抄よび電力 線については, 文献(16), (17) で提案された細線導体模擬 手法によりその半径を考慮した。ただし，電力線について は幾何学的平均距離により 4 導体の等価半径を算出し, そ の等価半径を考慮した。斜材等，いずれの座標軸とも平行 でない細線導体は，文献(18) に示されている階段近似によ りモデル化した。なお, 解析コードには電力中央研究所で 開発されたVSTL (Virtual Surge Test Lab.) (16)(19)を用いた。

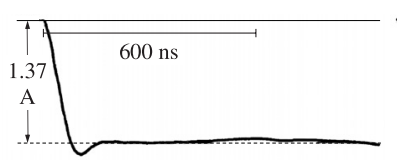

(a) Injected current

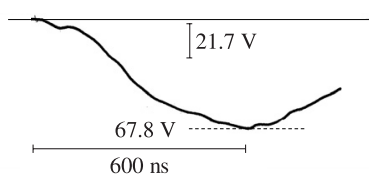

(b) Tower-top potential rise
図 2 塔頂電位上昇測定結果

Fig. 2. Measured result of the tower-top potential rise.

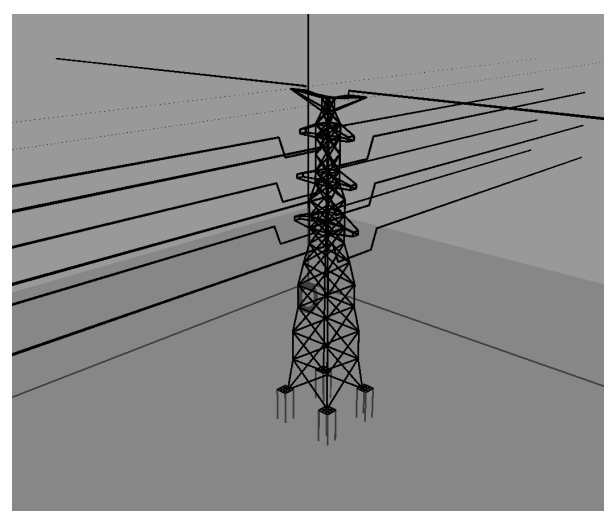

困 3 解析で使用された鉄塔構造

Fig. 3. Tower structure used in the simulation.

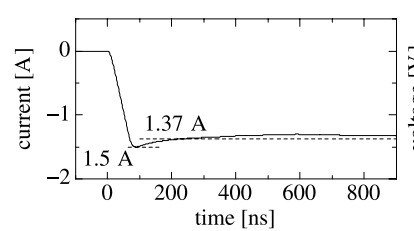

(a) Injected current

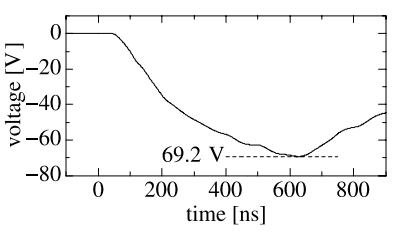

(b) Tower-top potential rise
図 4 塔頂電位上昇計算結果

Fig. 4. Calculated result of the tower-top potential rise. 
以上の条件で計算を行った結果 ${ }^{(20)}$ を図 4 に示す。塔頂電 位上昇波形について実測結果と計算結果を比較すると，実 測結果のピーク值が $67.8 \mathrm{~V}$, 計算結果では $69.2 \mathrm{~V}$ となり, その差約 $2 \%$ で一致している。また，波形も立ち上がり直 後のわずかな差異（計算結果のほうが立ち上がりが若干早 い）を除いて非常によく一致している。実測に用いられた 測定機器等の誤差を考えれば，FDTD 法により実測結果が ほぼ完全に再現できたといえる。

\section{FDTD 法による雷撃時ホーン間電圧の計算}

回路論の枠内で鉄塔をモデル化するための基礎デー夕を 得るため, FDTD 法により雷撃時ホーン間電圧の計算を行 う。図 5 に計算に用いた配置図を示す。実際の帰還雷撃で は，塔頂で正負逆極性の急峻波電流が発生し，一方が雷道 に沿って上方に，もう一方が鉄塔に沿って下方に伝搬する という形態となる。これを模擬するため計算では塔頂に電

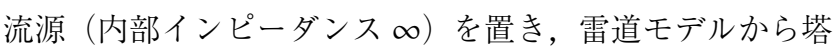
頂に向かって波高值 $1 \mathrm{~A}$ の電流を注入した。図 6 はその電 流源の波形である。発変電所の耐雷設計では, 通常, 雷撃 電流として立ち上がり $1 \mu \mathrm{s}$ のランプ波が想定され，また， 観測結果から夏季雷の波頭長の代表值が $2 \mu \mathrm{s}$ であることが 知られている(21)。そこで，現象を把握しやすいステップ波 電流と, 実用上重要となる立ち上がり $1 \mu \mathrm{s}$ および $2 \mu \mathrm{s}$ の ランプ波電流 (以降, $1 \mu \mathrm{s}$ ランプ波電流, $2 \mu \mathrm{s}$ ランプ波電 流と呼ぶ）の 3 種類について計算を行った。電流源から鉛 直上方へは，文献(19)，(22) で開発した雷道モデルを置き， 帰還雷撃が光速の約 $1 / 3$ で進展する (23)(24) ようにした。解 析空間については, 線路方向 $250 \mathrm{~m}$, 線路に垂直で大地と

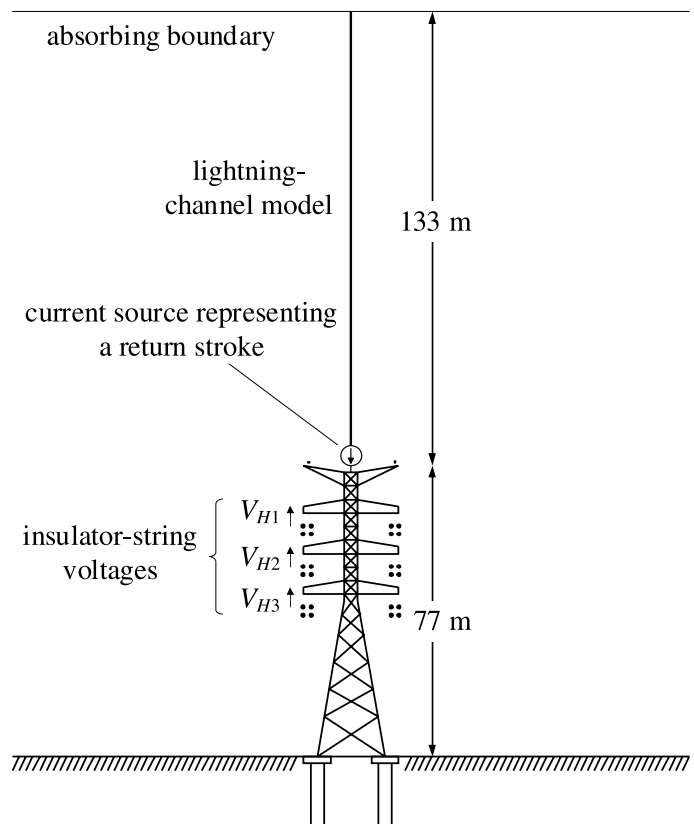

困 5 FDTD 法によるホーン間電圧計算の配置図

Fig. 5. Arrangement for the calculation of insulatorstring voltages by the FDTD method.
水平な方向 $150 \mathrm{~m}$, 鉛直方向 $250 \mathrm{~m}$ とし，空間刻みを $1 \mathrm{~m}$ として, 境界面の処理, 大地抵抗率, 鉄塔本体, 架空地線, 電力線については前節と同様の条件とした。以上の条件で 計算した結果を，図 7〜図 9 に示す。図 7 がステップ波電 流の場合の結果で, 図 8 , 図 9 が $1 \mu \mathrm{s}$ 抢よび $2 \mu \mathrm{s}$ ランプ波 電流の場合の結果である。図中 (a) には, 鉄塔流入電流 $I_{T}$

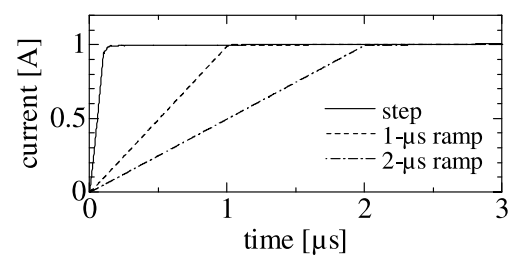

図 6 電流源の波形

Fig. 6. Waveforms of the current source.

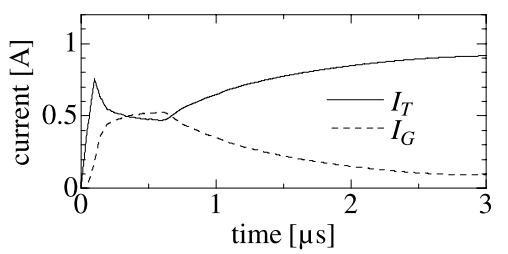

(a) $I_{T}$ : tower current and $I_{G}$ : ground wire current

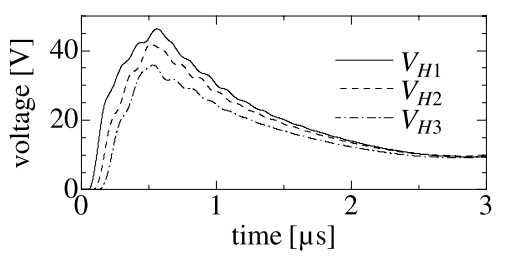

(b) $V_{H 1}, V_{H 2}, V_{H 3}$ : upper-, middle-, and lower-phase insulator-string voltages

図 7 ステップ波電流注入に対する FDTD 法 による計算結果

Fig. 7. Simulation result by the FDTD method for the step current injection.

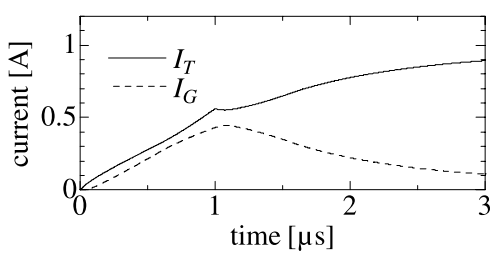

(a) $I_{T}$ : tower current and $I_{G}$ : ground wire current

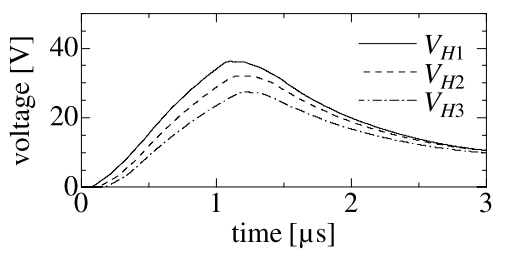

(b) $V_{H 1}, V_{H 2}, V_{H 3}$ : upper-, middle-, and lower-phase insulator-string voltages

図 $81 \mu \mathrm{s}$ ランプ波電流注入に対する FDTD 法 による計算結果

Fig. 8. Simulation result by the FDTD method for the $1-\mu \mathrm{s}$ ramp current injection. 


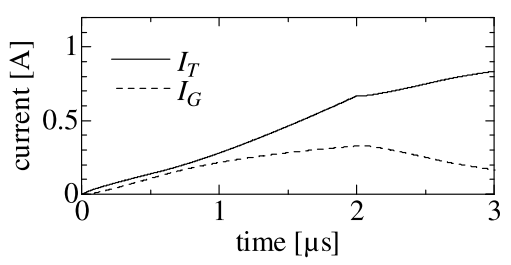

(a) $I_{T}$ : tower current and $I_{G}$ : ground wire current

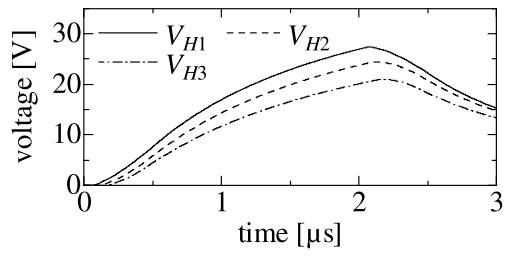

(b) $V_{H 1}, V_{H 2}, V_{H 3}$ : upper-, middle-, and lower-phase insulator-string voltages

図 $92 \mu \mathrm{s}$ ランプ波電流注入に対する FDTD 法 による計算結果

Fig. 9. Simulation result by the FDTD method for the $2-\mu$ s ramp current injection.

と架空地線流入電流 $I_{G}$ が示されているが，これらはいずれ も塔頂での值であり，また， $I_{G}$ は架空地線に流れ込む 4 箇 所の電流の合計值である。図中 (b) は上, 中, 下相のホー ン間電圧 $V_{H 1}, V_{H 2}, V_{H 3}$ の波形である。なお，吸収境界条 件の影響および雷道インピーダンスに関する考察をそれぞ れ付録 1,2 に示しておく。

\section{EMTP 解析用鉄塔モデルの導出}

〈4・1〉 モデルの概要 提案する鉄塔の回路論的モデ ルを図 10 に示す†。このモデルのパラメータは, 第 2,3 章 で得た FDTD 法による計算結果を用いて， $1 \mu \mathrm{s}$ および $2 \mu \mathrm{s}$ ランプ波電流注入の場合の結果をできるだけ正確に再現す るよう設定する。このモデルは, 塔頂一上相間, 上相一中相 間，中相一下相間，下相一塔脚間を分布定数線路モデルで表 現するいわゆる鉄塔の四段モデル ${ }^{(11) \sim(13)}$ の一種であるが，こ れに垂直導体インピーダンスの時間特性を表現するキャパ シタンス $C_{T}$ とホーン間電圧を正しく再現するための電圧 源 $e_{1}, e_{2}, e_{3}$ が付加されている。塔脚インピーダンスの等 価回路は従来の四段モデルを踏襲している。

さて, 図 7〜図 9 のとおり FDTD 法の計算結果は $V_{H 1}>$ $V_{H 2}>V_{H 3}$ となるが，この現象を回路論的モデルで再現する のは難しい。これは, 架空地線一電力線間の結合を考えたと き，上，中，下相の順に結合が大きいため，アーム電位と電力 線電位の差として与えられるホーン間電圧は, 回路論的には むしろ $V_{H 1}<V_{H 2}<V_{H 3}$ と計算されてしまうことによるけ。

\footnotetext{
†図中では, 鉄塔の左右両側に接続されている送電線をまとめて右 側に示している。

†回路論的モデルにおいて, ホーン間電圧は, 進行波の到来による各 アームの電位上昇から架空地線-電力線間結合による電位の低下と搭 脚からの負反射による電位の低下を差し引いたものとして計算される。 従って, 搭脚からの負反射がアーム電位波高值に与える影響が小さい 場合には，架空地線一電力線間の結合が上，中，下相の順に大きいた め, 回路論的には $V_{H 1}<V_{H 2}<V_{H 3}$ と計算されてしまうことになる。
}

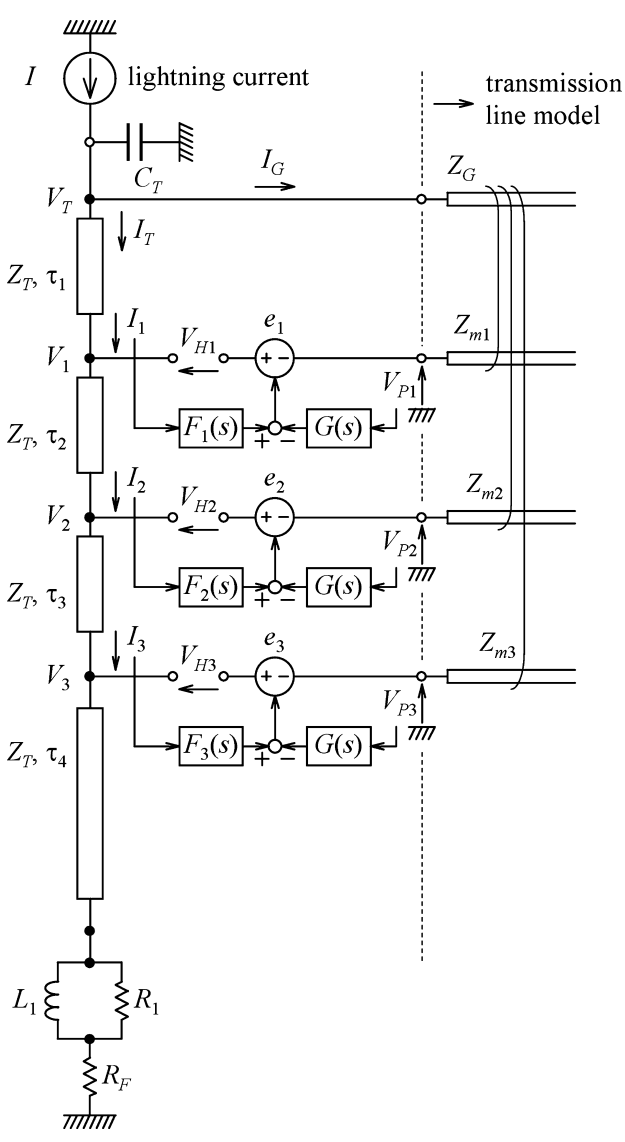

図 10 提案する鉄塔の回路論的モデル

Fig. 10. Proposed tower model based on the circuit theory.

実際の現象としては, 大地からの反射波が塔頂に戻って来る 前の速い時間領域では, 架空地線電流 $I_{G}$ が作る電磁界も未 だ架空地線一大地間で十分に形成されておらず, 理論的には この時間領域での結合が TEM 波仮定の結合率に従わない のは当然でありけ†, 実際には $V_{H 1}<V_{H 2}<V_{H 3}$ とはならな い。しかしながら, 送電線のモデルとして EMTPに用意さ れている分布定数線路モデルを利用する以上, 架空地線に雷 撃電流が流入した瞬間に TEM 波仮定の結合が生じてしま う。そこで，馬場らのモデル (12)(13) では， $V_{H 1}>V_{H 2}>V_{H 3}$ を実現するため, 鉄塔モデルの各段に抵抗を挿入して電圧 波高值を調節し，また，挿入した抵抗により各段で反射が 生じないよう各段のサージインピーダンスを調整している。 さらに，十分時間が経過した後にこれら調整用に挿入した 抵抗の影響が小さくなるよう，各抵抗と並列にインダクタ ンスを接続している。しかしながら, 上相のホーン間電圧 を正しく表現しょうとすると, 塔頂における鉄塔と架空地 線の電流分流比を正しく保つことができない ${ }^{(12)(13)}$ 。一方, 提案モデルでは, $e_{1}, e_{2}, e_{3}$ により $V_{H 1}>V_{H 2}>V_{H 3}$ を実 現しているため, 各段のサージインピーダンス $Z_{T}$ を鉄塔 と架空地線の電流分流比が正しくなるように決定すること

枯これに関して文献(12), (13) では, 初期の結合率が TEM 波仮定の ものよりも小さいことをシミュレーションにより明らかにしている。 


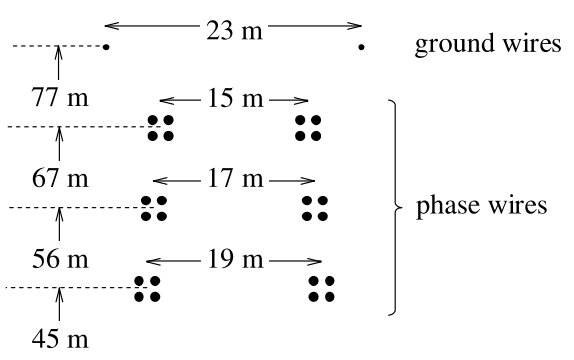

図 11 送電線の導体配置

Fig. 11. Conductor arrangement of a transmission line.

ができる。また，全段で $Z_{T}$ を同じ值とすることで各段で の反射を防ぐことができ，ひいては，各段に抵抗拉よびイ ンダクタンスを挿入する必要が無い。以下，図 3 に示した 鉄塔に図 11 の導体配置の送電線が架線されている場合を 例にとりモデルパラメータの決定方法を示す。

$\langle\mathbf{4} \cdot \mathbf{2}\rangle$ 各段のサージインピーダンスと伝搬時間

EMTP の Line Constants プログラムを用いて，架空地線 単体のサージインピーダンス $Z_{G}$, 架空地線と電力線上, 中, 下相間の相互サージインピーダンス $Z_{m 1}, Z_{m 2}, Z_{m 3}$ を計算 すると次の值となる（計算周波数 $1 \mathrm{MHz}$ )。

$$
\begin{array}{ll}
Z_{G}=172 \Omega, & Z_{m 1}=68.3 \Omega, \\
Z_{m 2}=51.4 \Omega, & Z_{m 3}=38.7 \Omega
\end{array}
$$

上記は鉄塔両側の送電線を 1 つにまとめた值であり，また， TEM 波仮定の值であるため EMTP 解析の結果はこれらの 值に従う。よって，これらの值を用いた場合に塔頂におけ る鉄塔と架空地線の分流比が FDTD 解析の結果と一致する ように，モデル各段のサージインピーダンス $Z_{T}$ を算出す ればよい。分流比がはっきりと読み取れるステップ波電流 注入のケース，すなわち図 7(a) から， $I_{G}$ がピーク值をと る $600 \mathrm{~ns}$ 付近の $I_{T}$ と $I_{G}$ の值を読み取ると, $I_{T}=0.471 \mathrm{~A}$, $I_{G}=0.526 \mathrm{~A}$ となる。これを再現するためには

$$
Z_{T}=\frac{I_{G}}{I_{T}} Z_{G}=192 \Omega
$$

とすればよい (各段共通)。

図 7(a) から， $I_{G}$ が立ち上がってピークをとるまでの時間 は $T=0.599 \mu \mathrm{s}$ と読及取れるが，これは塔体を往復する時 間に架空地線アーム片側（長さ $l_{\text {arm }}=11.5 \mathrm{~m}$ ）を伝搬する 時間を加えたものである。従って，鉄塔内のサージ伝搬速 度 $v$ は，これが各部で均一であると仮定することにより次 式で得られる(ただし， $h=77 \mathrm{~m}$ は鉄塔高）。

$$
v=\frac{2 h+l_{\text {arm }}}{T}=276 \mathrm{~m} / \mu \mathrm{s} .
$$

各段の伝搬時間は, 各段の長さが上部より $10 \mathrm{~m}, 11 \mathrm{~m}, 11 \mathrm{~m}$, $45 \mathrm{~m}$ であることより次の值となる。

$$
\begin{array}{ll}
\tau_{1}=36.2 \mathrm{~ns}, & \tau_{2}=39.8 \mathrm{~ns}, \\
\tau_{3}=39.8 \mathrm{~ns}, & \tau_{4}=163 \mathrm{~ns}
\end{array}
$$

な㧍，分布定数線路のモデルには無損失分布定数線路モデ ルを用いる。 $\langle\mathbf{4} \cdot 3\rangle$ 垂直導体インピーダンス時間特性の表現 垂 直導体のサージインピーダンスは時間の経過に伴って大き くなる特性を有している(9)。この特性を近似的に再現する キャパシタンス $C_{T}$ の值は, 図 4(b) に示したステップ波電 流注入時の塔頂電位上昇波形が有する時定数 $\tau_{T}$ から決定 する。図 4(b) より, 電位上昇のピーク值の $1-\mathrm{e}^{-1}$ 倍に到 達する時間は $\tau_{T}=0.211 \mu \mathrm{s}$ と読み取れるから, $C_{T}$ は次の 値となる。

$$
C_{T}=\frac{\tau_{T}}{Z_{T}}=1.10 \mathrm{nF}
$$

なお， $\tau_{T}$ の值が小さいため, $C_{T}$ は (1) 式の分流比にほとん ど影響を与えない。

〈4・4〉塔脚接地インピーダンス＼cjkstart従来の四段モデル を踏襲して, 定常接地抵抗を表す抵抗 $R_{F}$ と, サージが塔脚 で反射するときに見かけ上高い接地抵抗值を示す現象を模 擬する $R_{1}-L_{1}$ の並列回路により搭脚接地インピーダンスを 模擬する ${ }^{(12)(13)}$ 。図 10 の提案モデルにおいて, 時間が経過 して各段の分布定数部分のインピーダンスが短絡に近づく と, モデル全体のインピーダンスは $R_{1}, L_{1}, R_{F}$ によるイン ピーダンスに近づき，さらに時間が経過すると定常接地抵 抗 $R_{F}$ に収束していく。モデル全体のインピーダンスが $R_{1}$, $L_{1}, R_{F}$ によるインピーダンスに等しいと仮定すれば，塔頂 でステップ電流を注入した場合の鉄塔流入電流 $I_{T}$ は次式と なる。

$$
I_{T}=I_{T \infty}\left\{1-A \exp \left(-t / \tau_{g}\right)\right\}
$$

図 7(a)の $I_{T}$ の波形において，進行波現象が支配的な初期の 部分を除外し，時刻 1 3 $\mu$ s の部分を (4) 式で最小二乗近似 すれば次の值を得る。また，その近似結果を図 12 に示す。

$$
\begin{aligned}
& I_{T \infty}=0.959 \mathrm{~A}, \quad A=0.886, \\
& \tau_{g}=0.983 \mu \mathrm{s}
\end{aligned}
$$

$I_{T \infty}$ は $t \rightarrow \infty$ における $I_{T}$ の值であるから, $R_{F}$ の值は次式 で決定できる（雷撃電流の収束值が $1 \mathrm{~A}$ の場合）。

$$
R_{F}=\frac{Z_{G}}{I_{T \infty}}-Z_{G}=7.45 \Omega
$$

上記最小二乗フィッティングの過程において $R_{1}, L_{1}$ の情 報を多く含む初期の時間領域（時刻 $0 \sim 1 \mu \mathrm{s}$ ）のデー夕を 除外したため，その結果として得られた $I_{T \infty}, A, \tau_{g}$ より $R_{1}, L_{1}$ を決定すればその精度に問題が生じる。そこで, 付 録 3 の進行波解析の結果より， $1 \mu \mathrm{s}$ ランプ波電流を注入し た場合の時刻 $1 \mu \mathrm{s}$ に扔ける $I_{T}$ の值を正しく再現するよう に $R_{1}, L_{1}$ を決定する。図 8 より時刻 $1 \mu \mathrm{s}$ における $I_{T}$ の值 は $0.560 \mathrm{~A}$ となるが，この值を(付 1 ) 式，(付 2) 式に代入し て，塔脚より大地を見た電流反射係数を求めると $\theta=0.398$ となる。これより, 塔脚接地インピーダンスの反射初期の 值は

$$
Z_{F}=\frac{1-\theta}{1+\theta} Z_{T}=82.9 \Omega
$$


となり, $R_{1}$ は次の值となる。

$$
R_{1}=Z_{F}-R_{F}=75.4 \Omega
$$

$L_{1}$ の值は時定数 $\tau_{g}$ より次式で決定できる。

$$
L_{1}=\tau_{g} \frac{R_{1}\left(R_{F}+Z_{G}\right)}{R_{1}+R_{F}+Z_{G}}=52.2 \mu \mathrm{H}
$$

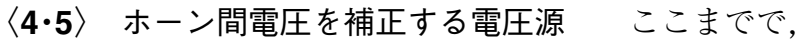
電圧源 $e_{1}, e_{2}, e_{3}$ の部分を除いて図 10 のモデルのパラメー 夕を決定できた。そこで， $e_{1}, e_{2}, e_{3}$ を省略（短絡）したモ デルを用い，雷撃電流を $1 \mu \mathrm{s}$ ランプ波とした場合について EMTP解析を行った結果を図 13 に示す。送電線のモデルに はJ. Marti モデル (FD-Line モデル) ${ }^{(25)}$ を用いた。図 13(a) のホーン間電圧波形を見ると，上，中，下相の順に波高值が 大きくなる現象を再現できていない。この実現象との相違 を補正するため, 電圧源 $e_{1}, e_{2}, e_{3}$ を各相のアーム一電力線 間にホーンと直列に挿入する。これら電圧源の值は，初期 の架空地線一電力線間の結合が TEM 波仮定の值より小さい ことを模擬し，かつ，各ホーン間電圧のピーク值が FDTD 法による計算結果と一致するよう設定する。

架空地線一電力線間の結合については，結合率が 0 から 時定数 $\tau_{g}$ で TEM 波仮定の值に収束していくようにするこ とで初期の小さな結合率を実現する。時定数として (4) 式

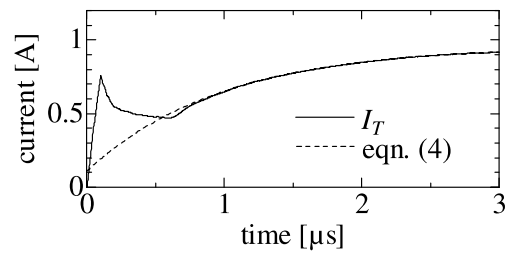

図 12 (4) 式による $I_{T}$ の近似

Fig. 12. Approximation of $I_{T}$ by (4).

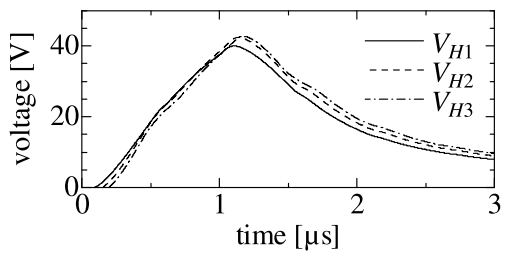

(a) $V_{H 1}, V_{H 2}, V_{H 3}$ : upper-, middle-, and lower-phase insulator-string voltages

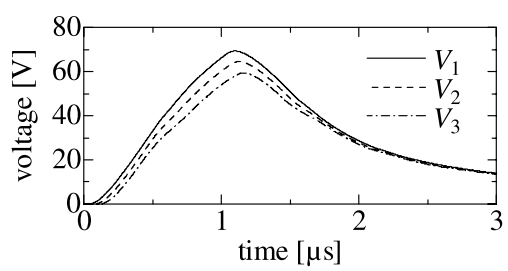

(b) $V_{H 1}, V_{H 2}, V_{H 3}$ : upper-, middle-, and lower-arm voltages to ground

図 $13 e_{1}, e_{2}, e_{3}$ を省略した場合の $1 \mu \mathrm{s}$ ランプ 波電流注入に対する EMTP 計算結果

Fig. 13. EMTP simulation result for the $1-\mu$ s ramp current injection when $e_{1}, e_{2}$, and $e_{3}$ are ignored.
の $\tau_{g}$ を用いた理由は, 塔体一塔脚系が TEM 波的に振舞う ようになるのに要する時定数と, 架空地線一電力線系のそれ とが同程度であると推測されるためである。架空地線に電 流が流入した瞬間に生じる TEM 波仮定の結合を打ち消し て, 時定数 $\tau_{g}$ で徐々に結合が形成されるようにするために は, 各電力線の電位 $V_{P i}$ を入力として

$$
G(s)=\frac{s \tau_{g}}{1+s \tau_{g}}
$$

なる伝達関数の応答を求め, これと逆位相の電圧を $e_{i}$ で発 生してやればよい。なお, 添え字 $i=1,2,3$ で上, 中, 下 相をそれぞれ表現しているが，以降もこの表記を用いる。

次に, 各段の塔体電流 $I_{i}$ を入力として伝達関数 $F_{i}(s)$ に 与え, その応答を $e_{i}$ で発生させることによりホーン間電圧 を FDTD 法による結果と一致させる。各段の塔体電流を入 力とした理由は，塔体電流により生じた電磁界が最終的に ホーン間電圧を決めていると考えたためである。上述の時 定数 $\tau_{g}$ で形成される結合を考慮した EMTP 計算により求 めた各ホーン間電圧の最大值 $V_{H i}^{\prime}$, FDTD 法により求めた 各ホーン間電圧の最大值 $V_{H i}$, そして, 両者の差 $\Delta V_{H i}$ を 求めたものを表 1 に示す。表中の $\Delta V_{H i}$ の值を $e_{i}$ で発生さ せることができれば，ホーン間電圧は FDTD 法による結果 と一致することになるが，その值を見ると $1 \mu \mathrm{s}$ ランプ波電 流注入時の值が $2 \mu \mathrm{s}$ ランプ波電流注入時の值の倍以上であ る。すなわち, 伝達関数 $F_{i}(s)$ は 2 次以上の微分特性を有 することになる。そこで，

$$
F_{i}(s)=\frac{k_{i} s^{2}}{(s+\alpha)\left(s+\beta_{i}\right)}
$$

を仮定し, 各段で $F_{i}(s)$ の応答が表 1 中の $\Delta V_{H i}$ の值と一致 するように係数 $k_{i}, \alpha, \beta_{i}$ を決定する。ただし，決定すべき 係数が 3 つであるのに対して，拘束条件が $1 \mu \mathrm{s}$ および $2 \mu \mathrm{s}$ ランプ波電流注入時の $\Delta V_{H i}$ の值 2 つであるため，条件を 1 つ与えてやる必要がある。そこで，(10) 式の分母の各項 が一次遅れを表し， $\alpha, \beta_{i}$ の逆数がそれぞれ時定数に対応し ていることに着目する。すなわち, $\alpha, \beta_{i}$ の逆数は, 分子の 2 階微分が生じる急峻な変化を和らげる時定数であり, 数 $\mu \mathrm{s}$ の現象に対して適用するのであればその数分の 1 程度の 值としておけばよいことが分かる。これより，本稿では，

$$
\alpha=1 /(0.25 \mu \mathrm{s})=4 \times 10^{6}
$$

表 1 ホーン間電圧最大値

Table 1. Maximum insulator-string voltages.

\begin{tabular}{l|c|c}
\hline & $1-\mu$ s ramp current & $2-\mu$ s ramp current \\
\hline$V_{H 1}^{\prime}$ (EMTP with $\left.\tau_{g}\right)$ & $57.1 \mathrm{~V}$ & $33.9 \mathrm{~V}$ \\
$V_{H 1}$ (FDTD) & $36.2 \mathrm{~V}$ & $27.4 \mathrm{~V}$ \\
$\Delta V_{H 1}$ (difference) & $20.9 \mathrm{~V}$ & $6.47 \mathrm{~V}$ \\
\hline$V_{H 2}^{\prime}$ (EMTP with $\left.\tau_{g}\right)$ & $54.8 \mathrm{~V}$ & $33.9 \mathrm{~V}$ \\
$V_{H 2}$ (FDTD) & $32.1 \mathrm{~V}$ & $24.5 \mathrm{~V}$ \\
$\Delta V_{H 2}$ (difference) & $22.8 \mathrm{~V}$ & $9.39 \mathrm{~V}$ \\
\hline$V_{H 3}^{\prime}$ (EMTP with $\left.\tau_{g}\right)$ & $51.7 \mathrm{~V}$ & $33.1 \mathrm{~V}$ \\
$V_{H 3}$ (FDTD) & $27.3 \mathrm{~V}$ & $21.0 \mathrm{~V}$ \\
$\Delta V_{H 3}$ (difference) & $24.4 \mathrm{~V}$ & $12.1 \mathrm{~V}$ \\
\hline
\end{tabular}




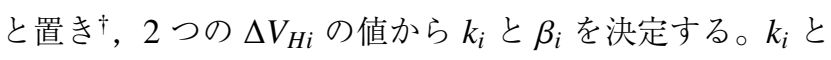
$\beta_{i}$ の決定過程の詳細は付録 4 に譲ることとし, ここではそ の概略を説明する。まず，各段において， $1 \mu \mathrm{s}$ および $2 \mu \mathrm{s}$ ランプ波電流注入時の塔体電流 $I_{i}$ を直線近似し，これに対 する (10) 式の応答を解析的に求める。ただし， $I_{i}$ を精度良 く直線近似できるように一次遅れフィル夕

$$
\frac{1}{1+10^{-7} s}
$$

を適用しておく。次に，得られた $1 \mu \mathrm{s}$ 拈よび $2 \mu \mathrm{s}$ ランプ波 電流注入に対する応答がピーク值で表 1 中の $\Delta V_{H i}$ の值と 一致するように 2 元の連立方程式を立て，これを解くこと により $k_{i}$ と $\beta_{i}$ を決定する。解くべき方程式は， $k_{i}, \beta_{i}$ に対 して非線形であるため，収束計算により解を求める必要が あるが， $I_{i}$ を何倍程度して $e_{i}$ の值とすればよいのかという 見当から $k_{i}$ の初期值を決め, $\beta_{i}$ の初期值を $\alpha$ と同じ值と することにより，簡単に収束させることがきる。本稿では， MATLAB ${ }^{(26)}$ に関数 fzero として実装されている収束計算 手法 ${ }^{27)}$ を用いたところ，いずれの段についても20 回程度 の反復計算で次の解を得ることができた。

$$
\begin{array}{ll}
k_{1}=181, & \beta_{1}=9.41 \times 10^{5} \\
k_{2}=161, & \beta_{2}=5.21 \times 10^{5} \\
k_{3}=151, & \beta_{2}=2.61 \times 10^{5}
\end{array}
$$

（11）式で適用した一次遅れフィルタも考慮すれば，伝達関 数 $F_{i}(s)$ の最終形は次式となる。

$$
F_{i}(s)=\frac{k_{i} s^{2}}{(s+\alpha)\left(s+\beta_{i}\right)\left(1+10^{-7} s\right)}
$$

図 10 中には， $e_{i}$ の值を $V_{P i}$ 抢よび $I_{i}$ で制御する様子が ブロック線図で示されているが，EMTP の最新版である EMTP-RV/EMTPWorks ${ }^{(28)}$ を用いれば図 10 のような電気 回路ーブロック線図混在図を画面上でそのまま入力できる。 また，過去のバージョンの EMTP においても TACS 等を用 いてモデル化することが可能である。

〈4・6〉 モデル導出手順全体について 以上で, FDTD 法によるホーン間電圧の計算結果より, EMTP 解析用鉄塔 モデルのパラメータを全て決定することができた。なお，土 壤の抵抗率や鉄塔構造が変われば，FDTD 法による解析か らやり直すことになるが, 市販のデスクトップ型計算機计を 用いた場合で第 3 章の計算に要する時間は約 2 時間であり, さほど長い計算時間を要するわけではない。また，隣接鉄 塔のモデル化に関する検討を付録 5 としておく。

\section{5. 提案モデルを用いた EMTP 計算結果}

前章でパラメー夕を同定したモデルを用いて $1 \mu \mathrm{s}$ および $2 \mu \mathrm{s}$ ランプ波電流を注入した場合の鉄塔流入電流，架空地

† $\alpha$ を $0.1 \mu \mathrm{s}$ から $0.4 \mu \mathrm{s}$ の範囲で変化させても計算結果に大きな影 響がなかったため, $1 \mu \mathrm{s}$ ランプ波電流の立ち上がり時間の $1 / 4$ を時定 数とした。

†† CPU に動作周波数 $2 \mathrm{GHz}$ の Opteron プロセッサを使用。

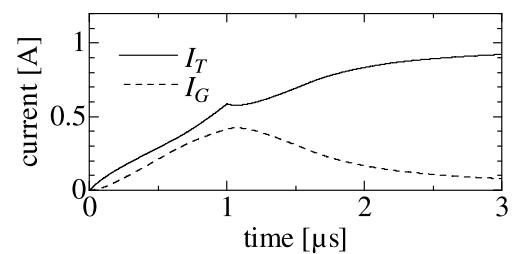

(a) $I_{T}$ : tower current and $I_{G}$ : ground wire current

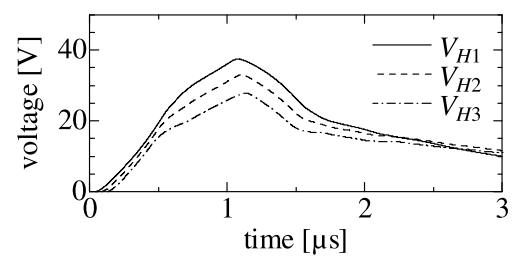

(b) $V_{H 1}, V_{H 2}, V_{H 3}$ : upper-, middle-, and lower-phase insulator-string voltages

図 14 提案モデルを用いた $1 \mu \mathrm{s}$ ランプ波電流 注入に対する EMTP 計算結果

Fig. 14. EMTP simulation result using the proposed model for the $1-\mu \mathrm{s}$ ramp current injection.

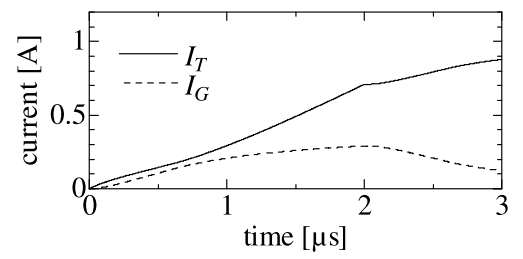

(a) $I_{T}$ : tower current and $I_{G}$ : ground wire current

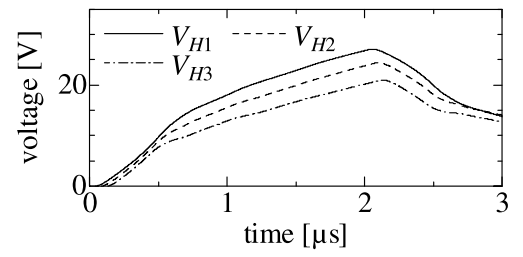

(b) $V_{H 1}, V_{H 2}, V_{H 3}$ : upper-, middle-, and lower-phase insulator-string voltages

図 15 提案モデルを用いた $2 \mu$ s ランプ波電流 注入に対する EMTP 計算結果

Fig. 15. EMTP simulation result using the proposed model for the $2-\mu \mathrm{s}$ ramp current injection.

\section{表 2 ホーン間電圧最大值の比較}

Table 2. Comparison of the maximum insulator-string voltages.

(a) 1- $\mu \mathrm{s}$ ramp current injection

\begin{tabular}{c|c|c|c}
\hline & FDTD result & EMTP result & deviation \\
\hline$V_{H 1}$ & $36.2 \mathrm{~V}$ & $37.5 \mathrm{~V}$ & $3.6 \%$ \\
$V_{H 2}$ & $32.1 \mathrm{~V}$ & $33.0 \mathrm{~V}$ & $2.8 \%$ \\
$V_{H 3}$ & $27.3 \mathrm{~V}$ & $27.8 \mathrm{~V}$ & $1.8 \%$ \\
\hline
\end{tabular}

(b) 2- $\mu \mathrm{s}$ ramp current injection

\begin{tabular}{c|c|c|c}
\hline & FDTD result & EMTP result & deviation \\
\hline$V_{H 1}$ & $27.4 \mathrm{~V}$ & $27.1 \mathrm{~V}$ & $-1.1 \%$ \\
$V_{H 2}$ & $24.5 \mathrm{~V}$ & $24.4 \mathrm{~V}$ & $-0.4 \%$ \\
$V_{H 3}$ & $21.0 \mathrm{~V}$ & $21.0 \mathrm{~V}$ & $0.0 \%$ \\
\hline
\end{tabular}


線流入電流，各ホーン間の電圧を EMTPにより計算した結 果を図 14, 図 15 に示す。図 8, 図 9 に示した FDTD 法に よる結果を良く再現している。特にホーン間電圧の最大值 については，表 2 に示すように FDTD 解析の結果を正確に 再現している。なお，雷撃は電流源模擬（雷道インピーダ ンス $\infty)$ ，送電線はJ. Marti モデルとした。

\section{6. おわりに}

本論文では，FDTD 法を用いた数值電磁界解析の結果に 基づいて, EMTPによる雷サージ解析に使用できる送電鉄 塔のモデルを導出する方法について述べた。本論文で実施 した FDTD解析では, 大地の抵抗率, 鉄塔のアームや斜材, 土中の基礎構造，帰還雷撃の進展速度等，従来の解析では 無視あるいは簡略化されていた部分についてもできるだけ 詳細にモデル化を行った。また，過去に行われた $500 \mathrm{kV}$ 送 電鉄塔の塔頂電位上昇試験について試験結果と FDTD 法に よる計算結果を比較することにより，その解析精度が十分 であることを明らかとした。EMTP解析に使用できる鉄塔 モデルについては，新たな鉄塔モデルを提案することによ り，モデル定数の決定過程を一意的なものとした。従来の モデル化手法が定数の決定に試行錯誤的な過程を含んでい たことを考えると，より汎用的な手法を提案できたといえ る。また，先の $500 \mathrm{kV}$ 送電鉄塔について EMTP 解析用の モデルを導出する過程を例示し，導出したモデルを用いた EMTP 計算結果がFDTD 法による計算結果を良く再現する ことを示した。今後は，雷放電路の傾きが計算值に与える 影響や提案モデルとアークホーン・フラッシオーバモデル との組み合わせについて検討を行いたい。

本研究を行うにあたり，データをご提供いただいた東京 電力株式会社の高見 潤氏，データ作成を行っていただいた 湘南工科大学大学院の小俣 勇氏，ならびに，有益なご助言 をいただいた（財）電力中央研究所 電力技術研究所の松原 廣治上席研究員，横山茂首席研究員に感謝致します。

(平成 17 年 9 月 14 日受付，平成 18 年 8 月 23 日再受付)

\section{文献}

(1) M. Ishii and Y. Baba: "Numerical electromagnetic field analysis of tower surge response", IEEE Trans. Power Delivery, Vol.12, No.1, pp.483-488 (1997-1)

(2) C.A. Jordan: "Lightning computations for transmission lines with overhead ground wires, Part II", General Electric Review, Vol.37, No.4, pp.180-186 (1934-4)

(3) A. Ametani, Y. Kasai, J. Sawada, A. Mochizuki, and T. Yamada: "Frequency-dependent impedance of vertical conductors and a multiconductor tower model", IEE Proc.-Gener. Transm. Distrib., Vol.141, No.4, pp.339-345 (1994-7)

(4) R. Lundholm, R.B. Finn Jr., and W.S. Price: "Calculation of transmission line lightning voltages by field concepts", AIEE Trans. Power Apparatus and Systems, Vol.77, pp.1271-1283 (1958-2)

(5) C.F. Wagner and A.R. Hileman: "A new approach to the calculation of the lightning performance of transmission lines III-a simplified method: stroke to tower", AIEE Trans. Power Apparatus Syst., Vol.79, pp.589-603 (196010)

(6) M.A. Sargent and M. Darveniza: "Tower surge impedance", IEEE Trans. Power Apparatus Syst., Vol.PAS-88, No.5, pp.680-687 (1969-5)
(7) H. Motoyama and H. Matsubara: "Analytical and experimental study on surge response of transmission tower", IEEE Trans. Power Delivery, Vol.15, No.2, pp.812-819 (2000-4)

(8) M. Kawai: "Studies of the surge response on a trans-mission line tower", IEEE Trans. Power Apparatus Syst., Vol.PAS-83, No.1, pp.30-34 (1964-1)

(9) T. Hara, O. Yamamoto, M. Hayashi, and C. Uenosono: "Empirical formulas of surge impedance for single and multiple vertical cylinder", T. IEE Japan, Vol.110-B, No.2, pp.129-137 (1990-2) (in Japanese) 原 武久・山本 修・林 宗明・上之園親佐：「垂直導体および垂直 複導体サージインピーダンスの実験式」, 電学論 B, 110, 2, pp.129-137 (1990-2)

(10) T. Hara and O. Yamamoto: "Modelling of a transmission tower for lightning-surge analysis", IEE Proc.-Gener. Transm. Distrib., Vol.143, No.3, pp.283-289 (1996-5)

(11) M. Ishii, T. Kawamura, T. Kouno, E. Ohsaki, K. Murotani, and T. Higuchi: "Multistory transmission tower model for lightning surge analysis", IEEE Trans. Power Delivery, Vol.6, No.3, pp.1327-1335 (1991-7)

12) Y. Baba and M. Ishii: "Numerical electromagnetic field analysis on lightning surge response of tower with shield wire", IEEE Trans. Power Delivery, Vol.15, No.3, pp.1010-1015 (2000-7)

13) Y. Baba and M. Ishii: "Tower models for fast-front lightning currents", $T$ IEE Japan, Vol.120-B, No.1, pp.18-23 (2000-1)

14) H.W. Dommel: "Digital computer solution of electromagnetic transients in single- and multi-phase networks", IEEE Trans. Power Apparatus Syst., Vol.PAS-88, No.4, pp.388-399 (1969-4)

15) H. Matsubara, H. Motoyama, and K. Wakamatsu: "Field-test result of the lightning-surge response of a 500-kV transmission line", 1989 National Convention Record IEE Japan, No.1237 (1989) (in Japanese)

松原広治・本山英器・若松啓治：「500 kV 送電線の雷サージ特性実 測結果」, 平成元年電気学会全国大会, No.1237 (1989)

16) T. Noda and S. Yokoyama: "Development of a general surge analysis program based on the FDTD method", T. IEE Japan, Vol.121-B, No.5, pp.625632 (2001-5) (in Japanese)

野田 环・横山 茂：「FDTD 法に基づく汎用サージ解析プログラム の開発」, 電学論 B, 121, 5, pp.625-632 (2001-5)

17) T. Noda and S. Yokoyama: "Thin wire representation in finite difference time domain surge simulation”, IEEE Trans. Power Delivery, Vol.17, No.3, pp.840-847 (2002-7)

(18) T. Noda, R. Yonezawa, S. Yokoyama, and Y. Takahashi: "Error in propagation velocity due to staircase approximation of an inclined thin wire in FDTD surge simulation", IEEE Trans. Power Delivery, Vol.19, No.4, pp.1913-1918 (2004-10)

19) T. Noda, A. Tatematsu, and S. Yokoyama: "Improvements of an FDTDbased surge simulation code and its application to the lightning overvoltage calculation of a transmission tower", Proc. IPST 2005 (Int. Conf. on Power Systems Transients), No.05-138, Montreal, Canada (2005-6)

(20) I. Omata, T. Noda, H. Matsubara, S. Yokoyama, and Y. Ebinuma: "Reproduction of a tower surge test result using the FDTD method", 2005 National Convention Record IEE Japan, No.7-101 (2005) (in Japanese)

小俣 勇・野田 玩·松原広治・横山茂・海老沼康光：「FDTD 法 による鉄塔サージ試験結果の再現」, 平成 17 年電気学会全国大会, No.7-101 (2005)

21) Subcommittee for Power Stations and Substations, Lightning Protection Design Committee: "Guide to lightning protection design of power stations, substations and underground transmission lines", CRIEPI Reports, T40 (1995-12) (in Japanese)

耐雷設計委員会発変電分科会：「発変電所および地中送電線の耐雷 設計ガイド」,電中研研報, T40 (1995-12)

(22) A. Tatematsu, T. Noda, and S. Yokoyama: "Development of simulation technique of lightning-induced voltages on distribution lines using the FDTD method", CRIEPI Reports, H04009 (2005-7) (in Japanese) 立松明芳・野田 环・横山 茂:「FDTD 法による配電線誘導雷電圧 計算手法の開発」,電中研研報, H04009 (2005-7)

(23) B.F.J. Schonland: "The lightning discharge", Encyclopedia of Physics, S. Flügge, Ed., Vol.22, Section 7, 652, pp.576-628, Springer-Verlag, Berlin (1956)

(24) V.P. Idone and R.E. Orville: "Lightning return stroke velocities in the Thunderstorm Research Internatinal Program (TRIP)", J. Geophys. Res., Vol.87, No.C7, pp.4903-4915 (1982)

25) J. R. Marti: "Accurate modelling of frequency-dependent transmission lines in electromagnetic transient simulations", IEEE Trans. Power Apparatus Syst., Vol.PAS-101, No.1, pp.147-157 (1982-1)

(26) http://www.mathworks.com/

(27) G.E. Forsythe, M.A. Malcolm, and C.B. Moler: Computer methods for mathematical computations, Prentice-Hall (1976)

(28) http://www.emtp.com/ 
(29) T. Uno: "Finite Difference Time Domain Method for Electromagnetic Field and Antennas", Corona Publishing, Co., Ltd. (1998) (in Japanese) 宇野 亨：FDTD 法による電磁界およびアンテナ解析, コロナ社 (1998)

(30) Investigating R\&D Committee on Lightning Parameters for Insulation and Protection Designs of Power Systems: "Lightning parameters for insulation and protection designs of power systems", IEEJ Technical Report, No.1033 (2005) (in Japanese)

電力設備のための雷パラメー夕選定方法調査専門委員会 : 「電力設 備のための雷パラメータ選定法」, 電気学会技術報告, No.1033 (2005)

(31) Y. Baba and V.A. Rakov: "On the use of lumped sources in lightning return stroke models", Journal of Geophysical Research, Vol.110, D03101, doi:10.1029/2004JD005202 (2005)

(32) Y. Baba and M. Ishii: "Numerical electromagnetic field analysis on measuring methods of tower surge impedance", IEEE Trans. Power Delivery, Vol.14, No.2, pp.630-635 (1999-4)

\section{付 録}

\section{1. 吸収境界条件が計算結果に与える影響}

ここでは，FDTD 法による計算において，吸収境界条件 が計算結果に与える影響を検討する。第 3 章と同一の条件 の解析空間内に架空地線 1 条のみを置き，その中央を架線 方向にステップ波状の電流源で励振するという計算を行っ た。その結果が付図 1 で，電流源の発生した電流波形と電

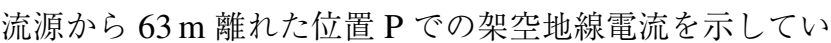
る。架空地線の末端は境界吸収条件で終端されているため,

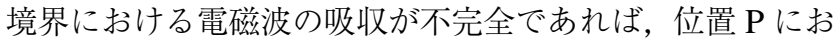
いて反射波が観測されることになる。しかしながら，付図 1 では $1 \mu \mathrm{s}$ 以降の部分に僅かな差異が確認できるだけであり， 本稿で示した FDTD 法による解析結果は，吸収境界条件の 影響をほとんど受けていないといえる。

なお，本稿の FDTD 解析では 2 次の Liao の吸収境界条 件を適用することによる不安定現象は確認されなかったた め，吸収境界条件安定化のための係数 $d$ を 0 とした（ $d$ に ついては文献 (29)の (2.47) 式を参照のこと)。ただし，例 えば, $d=0.0075$ とした場合には 2 割強の反射波が確認さ れる。

\section{2. 雷道インピーダンスについて}

近年，雷道インピーダンスを $1 \mathrm{k} \Omega$ 程度と仮定することで 雷撃時の諸現象を正確に説明できることが分かってきた ${ }^{(30)}$ 。 従来は雷撃を電流波形（電流源）で与えるのが一般的であ り, EMTP 等の回路解析手法では無限遠点から雷撃点に向 けて注入する電流源と並列接続する雷道インピーダンス（抵 抗）の值を $1 \mathrm{k} \Omega$ に設定すればよい。一方，FDTD法やモー メント法等の数值電磁解解析では空間をモデル化するため, 雷撃を電流波形で与える場合には雷道インピーダンスの表 現が難しい。これは，雷道インピーダンスは本来雷撃電流

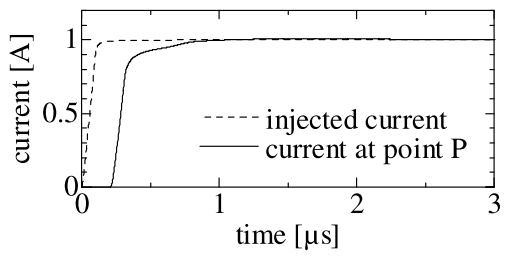

付図 1 吸収境界からの反射

app. Fig. 1. Reflection from an absorbing boundary.
を発生する電流源と並列に接続されるべきものであるが, 空間中に雷道そのものを模擬した場合，構造上これと電流 源を直列に接続するしかなく，並列に接続できないためで ある。第 3 章で行った FDTD 解析では, 電流源の存在に より塔頂から雷道を見たインピーダンスは無限大となって いる。これは文献(12), (13) の計算条件と同じではあるが, 塔脚や隣接鉄塔で反射してきた電流の一部が雷道に戻る現 象を考慮できないため，将来は改良されるべきである。

ごく最近，電流源ではなく電圧源により雷撃電流を発生 させる雷撃のモデル化手法 ${ }^{(31)}$ が提案された。この手法を用 いれば，FDTD 法やモーメント法で正しく雷道インピーダ ンスの值を表現することが可能となる。ただ，電流波形 や電流波高值の形で与えられる雷撃特性を電圧源で表現す るには被雷撃物のインピーダンスを用いて換算を行う必要 があるが，通常被雷撃物のインピーダンスは既知では無い。 今後, 研究が進み上記の問題を解決することが望まれる。

\section{3. 進行波解析}

図 10 の回路に進行波解析を適用し，1 $1 \mu \mathrm{s}$ ランプ波電流 が注入された場合の過渡現象を計算する。塔頂に注入され た電流は塔脚で反射し再び塔頂に戻ってくるが，進行波解 析により時刻 $1 \mu \mathrm{s}$ におけるこの電流成分 $I_{T r}$ を計算すると

$$
I_{T r(t=1 \mu \mathrm{s})}=\frac{1-\left(1-I_{T(t=1 \mu \mathrm{s})}\right)\left(1+\frac{Z_{G}}{Z_{T}}\right)}{2} \ldots \ldots
$$

となる。ただし， $I_{T(t=1 \mu \mathrm{s})}$ は時刻 $1 \mu \mathrm{s}$ における塔頂流入電 流值であり，また， $C_{T}$ の存在は無視している。

次に，塔体より塔脚を見たときの電流反射係数 $\theta$ は，入 射した電流と反射した電流の比であるから，

$$
\theta=\frac{I_{T r(t=1 \mu \mathrm{s})}}{I_{T(t=1 \mu \mathrm{s}-2 \tau)}}
$$

となる。ただし， $\tau=h / v$ は塔体伝搬時間である。(付 1$)$, (付 2 ) 式における $I_{T}$ の值は, $1 \mu \mathrm{s}$ ランプ波電流の $Z_{T}$ と $Z_{G}$ による分流であるから簡単に計算できる。

\section{4. $\boldsymbol{k}_{i}$ と $\beta_{i}$ の決定}

(11) 式の一次遅れフィル夕を $I_{i}$ に適用すれば，その応答 はほぼ直線状となる。これを $I_{i}^{\prime}$ と書けば，次式で近似する ことができる。

$$
\left.\begin{array}{l}
I_{i}^{\prime}=I_{0 i}\left\{1-\exp \left(-a\left(t-t_{0 i}\right)\right)\right\} \\
a=1 /\left(100 t_{f}\right)
\end{array}\right\}
$$

上式では注入電流の立ち上がり $t_{f}$ に対して十分長い $(100$ 倍）時定数を設定することにより，指数関数の立ち上がり 部が直線状となることを利用している。係数 $I_{0 i}, t_{0 i}$ の值は, $I_{i}^{\prime}$ が最も直線状となる $t=t_{f}$ 付近で $I_{i}^{\prime}$ を直線 $I_{i}^{\prime}=m t+n$ と置くことにより，次式で算出することができる。

$$
t_{0 i}=-\frac{n}{m}, \quad I_{0 i}=\frac{I_{i\left(t=t_{f}\right)}}{1-\exp \left(-a\left(t_{f}-t_{0 i}\right)\right)} \cdots \cdots
$$

(付 3) 式をラプラス変換し (10) 式の伝達関数に乗じ, さら に逆ラプラス変換すると次式の時間応答を得る。 


$$
\begin{array}{r}
k_{i} a I_{0 i}\left[\frac{a \exp (-a t)}{(a-\alpha)\left(\beta_{i}-a\right)}+\frac{\alpha \exp (-\alpha t)}{(a-\alpha)\left(\alpha-\beta_{i}\right)}\right. \\
\left.+\frac{\beta_{i} \exp \left(-\beta_{i} t\right)}{\left(\alpha-\beta_{i}\right)\left(\beta_{i}-a\right)}\right] \ldots \ldots \ldots \ldots \ldots
\end{array}
$$

上式の $k_{i}$ を除いた部分を関数 $u_{i}\left(t, a, \beta_{i}\right)$ とおけげ, $k_{i} u_{i}\left(t_{f}, a\right.$, $\left.\beta_{i}\right)$ が表 1 の $\Delta V_{H i}$ に等しいという条件が拘束条件となる。 すなわち, $t_{f}=1 \mu \mathrm{s}$ 抢よび $t_{f}=2 \mu \mathrm{s}$ について次の 2 式が 得られる。

$$
\left.\begin{array}{l}
k_{i} u_{i}\left(1 \mu \mathrm{s}, a_{1}, \beta_{i}\right)=\Delta V_{H i\left(t_{f}=1 \mu \mathrm{s}\right)} \\
k_{i} u_{i}\left(2 \mu \mathrm{s}, a_{2}, \beta_{i}\right)=\Delta V_{H i\left(t_{f}=2 \mu \mathrm{s}\right)}
\end{array}\right\}
$$

ただし， $a_{1} ， a_{2}$ はそれぞれ (付 3 ) 式の $a$ に $t_{f}=1 \mu \mathrm{s}$ 㧍よび $t_{f}=2 \mu \mathrm{s}$ を代入した值である。上記の連立方程式を解くに は， $k_{i}$ を消去して $\beta_{i}$ に関するスカラ問題に帰着することが 得策である。この $\beta_{i}$ に関するスカラ方程式は文献(27)の 収束計算手法により容易に解くことができる。 $\beta_{i}$ が得られ れば, $\beta_{i}$ の值を(付 6) 式のいずれかに代入することで $k_{i}$ の 值を得ることができる。

\section{5. 隣接鉄塔のモデル化について}

雷撃鉄塔で架空地線に分流した電流波は隣接鉄塔まで伝 搬し，隣接鉄塔のサージインピーダンスおよび接地抵抗で 決まる反射係数で反射して再び雷撃鉄塔まで戻って来る。 すなわち，上記反射波が戻って来た後の時間領域では，隣 接鉄塔のサージインピーダンスが計算結果に影響を与える ことになる。ただし，隣接鉄塔に扔いて雷撃電流は架空地 線からの流入すなわち横方向からの流入となるため, 雷撃 鉄塔とは異なった電磁界分布となり，そのサージインピー ダンスは雷撃鉄塔のそれの $80 \%$ 程度の值となる ${ }^{(32) 。}$

そこで，隣接鉄塔のサージインピーダンスが計算結果に 与える影響を検討するため, EMTP 上で鉄塔 3 基を模擬し た計算を行った。各鉄塔には本文中で導出したモデルを用 いた。送電線はその径間長を $500 \mathrm{~m}$ とし，J. Marti モデル で模擬した。また，両側の鉄塔より遠方にも径間長 $500 \mathrm{~m}$ の送電線モデルを接続し, 中央の鉄塔を基準として約 $6.7 \mu \mathrm{s}$ 迄の時間領域のみを見ることで，遠方からの反射を無視し た。中央の鉄塔を雷撃鉄塔とし, 雷道インピーダンス $1 \mathrm{k} \Omega$ を考慮して波高值 $1 \mathrm{~A}$ ，立ち上がり $1 \mu \mathrm{s}$ のランプ波を塔頂 に注入した。以上の条件で, 両側の隣接鉄塔のサージイン

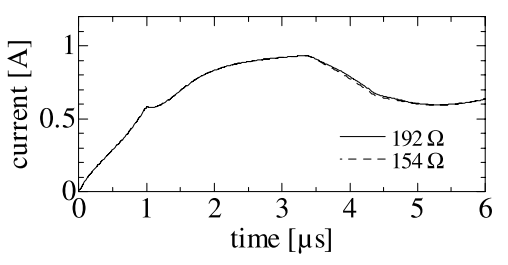

(a) $I_{T}$ : tower current

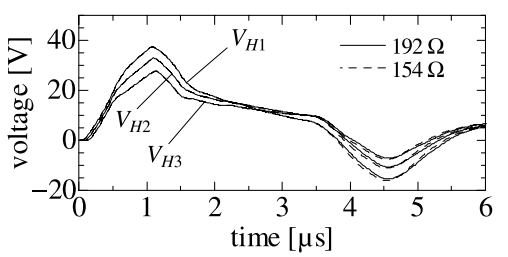

(b) $V_{H 1}, V_{H 2}, V_{H 3}$ : upper-, middle-, and lower-phase insulator-string voltages

付図 2 隣接鉄塔のサージインピーダンスの影響 app. Fig. 2. Effects of the surge impedance of the neighboring towers.

ピーダンスを雷撃鉄塔と同じ $192 \Omega$ としたケース, そして, $80 \%$ 值である $154 \Omega$ としたケースの 2 ケースについて計算 を行ったところ, 付図 2 の結果を得た。この結果より, 隣 接鉄塔のサージインピーダンス值が雷撃鉄塔の電流やホー ン間電圧に与える影響は極めて小さく，隣接鉄塔には雷撃 鉄塔と同じモデルもしくは文献 (32) の結果を踏まえてサー ジインピーダンスを小さめに見積もったモデルのいずれを 用いても良いことが分かる。

なお，隣接鉄塔のホーン間電圧にも着目して計算を行う 場合には，架空地線から電流波が入射するケースについて FDTD 解析からやり直し, モデル化手法を再度吟味する必 要があると考えられる。

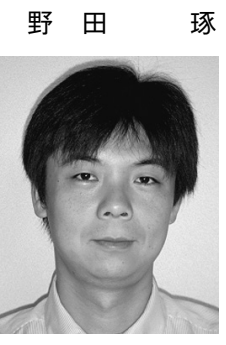

琢（正員） 1997 年同志社大学大学院工学研究科博 士後期課程修了。博士 (工学)。同年 4 月 (財) 電 力中央研究所入所。現在, 同所電力技術研究所主 任研究員。1995 年米国エネルギー省 BPA コンサ ルタント。2001 2002 年トロント大学客員研究 員。2005 年より同志社大学大学院客員教授兼任 (連携大学院)。電力系統の過渡現象解析手法に関 する研究に従事。 